\title{
Postęp w badaniach nad peptydami natriuretycznymi
}

\author{
Progress in study on natriuretic peptides
}

\author{
Stanisław Surma ${ }^{1}$ (D), Edward Bańkowski \\ ${ }^{1}$ Wydział Nauk Medycznych Śląskiego Uniwersytetu Medycznego w Katowicach \\ ${ }^{2}$ Zakład Biochemii Lekarskiej Uniwersytetu Medycznego w Białymstoku
}

\section{Streszczenie}

Peptydy natriuretyczne (NP) są hormonami głównie zaangażowanymi w regulację gospodarki wodno-elektrolitowej oraz regulację czynności układu krążenia. Dotychczas opisano sześć klasycznych NP: peptyd natriuretyczny typu A, urodylatynę, peptyd natriuretyczny typu $B$, peptyd natriuretyczny typu $C$, peptyd natriuretyczny typu $D$ oraz uroguanylinę. Do rodziny NP zalicza się również osteokrynę i muskulinę, które wykazują odmienne działania metaboliczne. Peptydy natriuretyczne realizują swoje działania biologiczne poprzez oddziaływanie z trzema receptorami błonowymi. Biodostępność tych związków jest regulowana między innymi przez neprylizynę. Stężenie NP w osoczu zmienia się w przebiegu wielu chorób. Do najważniejszych z nich zalicza się niewydolność serca (HF). W wytycznych Europejskiego Towarzystwa Kardiologicznego wskazuje się, że oznaczanie stężenia NP w osoczu jest pomocne w diagnostyce HF.

Poznanie fizjologii NP doprowadziło do poszukiwań nowych leków, które naśladowałyby ich korzystne działanie. Poza korzystnym wpływem NP na układ krążenia wykazano, że związki te biorą udział w regulacji wielu innych procesów metabolicznych - między innymi w regulacji ośrodka głodu i sytości w podwzgórzu.

Celem niniejszej pracy jest przedstawienie definicji, historii i mechanizmów działania NP, a także ich roli w fizjologii i patologii człowieka oraz przedstawienie zagadnień klinicznych związanych z tymi hormonami.

Słowa kluczowe: peptydy natriuretyczne, układ sercowo-naczyniowy, niewydolność serca, choroby układu sercowo-naczyniowego

Folia Cardiologica 2020; 15, 2: 137-148

\section{Definicja peptydów natriuretycznych}

Peptydy natriuretyczne (NP, natriuretic peptides) są oligopeptydowymi hormonami głównie zaangażowanymi w regulację gospodarki wodno-elektrolitowej oraz regulację czynności układu krążenia. Dotychczas zidentyfikowano sześć NP występujących w organizmie człowieka. Rodzina NP obejmuje przedsionkowy peptyd natriuretyczny (ANP, atrial natriuretic peptide), urodylatyne (URO, urodilatin; tzw. nerkowy peptyd natriuretyczny), peptyd natriuretyczny typu B (BNP, B-type natriuretic peptide), peptyd natriuretyczny typu $\mathrm{C}$ (CNP, C-type natriuretic peptide), peptyd natriuretyczny typu D (DNP, D-type natriuretic peptide) oraz uroguanylinę [1, 2]. Do tej rodziny zalicza się również osteokrynę (OSTN, osteocrin) i muskulinę, które nie są typowymi NP, ale oddziałują z receptorami tych związków $[3,4]$. Znane są trzy typy receptorów dla NP: receptor A (NPR-A, natriuretic peptide receptor type $A$ ) lub inaczej cyklaza guanylanowa A (GC-A, guanylate cyclase A), który wiąże ANP i BNP oraz urodylatynę; receptor B (NPR-B, natriuretic peptide receptor type $B$ ), który jest wysoce specyficzny dla CNP, oraz receptor C (NPR-C, natriuretic peptide receptor type $\mathrm{C}$ ), z którym oddziałują ANP, BNP, URO oraz CNP [5]. 


\section{Rys historyczny}

Historia NP sięga 1956 roku, kiedy Kish i wsp. [6] w trakcie badań z użyciem mikroskopu elektronowego opisali ziarnistości występujące w kardiomiocytach przedsionków, które okazały się podobne do ziarnistości występujących w gruczołach endokrynnych. Jamieson i Palade w 1964 roku stwierdzili, że część kardiomiocytów przedsionków zawiera ziarnistości wydzielnicze [7]. Następnie w 1981 roku de Bold i wsp. [8] wykazali, że podanie szczurom dożylnie homogenatu z przedsionków serca bardzo wyraźnie nasilało diurezę oraz natriurezę $i$ istotnie obniżało ciśnienie tętnicze. W dalszych pracach dokonano izolacji z tego wyciągu substancji chemicznej, którą nazwano przedsionkowym peptydem natriuretycznym [8]. Pierwszym opisanym NP był zatem ANP. Kolejny odkryty NP to BNP, który po raz pierwszy został wyizolowany w 1988 roku z mózgu świń przez Sudoha. Kolejnym NP był CNP - również odkryty przez Sudoha w 1990 roku podczas badań nad ekstraktami z mózgów świń [9]. W 1988 roku Shultz-Knappe i wsp. odkryli i opisali URO [10]. Rok 1992 przyniósł odkrycie kolejnego, piątego już NP, którym jest DNP [11]. Uroguanylinę odkryto w organizmie szczura w 1992 roku, natomiast rok później wykryto jej obecność u oposów [12]. Muskulinę odkryli Nishizawa i wsp. w 2003 roku [4]. W tym samym roku Thomas i wsp. odkryli i opisali OSTN [3].

\section{Epidemiologia chorób układu krążenia w Polsce i na świecie}

Choroby układu krążenia (CVD, cardiovascular diseases) są główną przyczyną zgonów w Polsce. Wśród kobiet umieralność z powodu CVD jest wyższa. Według danych Głównego Urzędu Statystycznego (GUS) CVD spowodowały w 2015 roku 51\% zgonów wśród kobiet oraz 41\% wśród mężczyzn. Dane dotyczące populacji europejskiej wskazują, że wśród przyczyn zgonów mężczyzn CVD stanowiły 42\%, natomiast odsetek ten wśród kobiet wynosił 52\% [13]. Tak duże rozpowszechnienie tych chorób jest spowodowane wieloma uwarunkowaniami. Po pierwsze warto zwrócić uwagę na duże rozpowszechnienie czynników ryzyka ich wystąpienia. Hipercholesterolemia, według badania NATPOL 2011, jest najczęściej występującym czynnikiem ryzyka CVD w Polsce i dotyka 18 mln osób (61\%) [14]. Po drugie w społeczeństwie panuje niska świadomość CVD i wywołujących je czynników. Przeglądy badań wykonane przez Surmę i wsp. $[15,16]$ wskazują, że ta niska świadomość dotyczy zarówno osób młodych, jak i dorosłych.

Tak duże rozpowszechnienie czynników ryzyka CVD oraz samych CVD sprawiło, że usilnie poszukuje się wskaźników laboratoryjnych (biomarkerów), które pomogłyby we wczesnym diagnozowaniu tych schorzeń, umożliwiając ich skuteczniejsze leczenie. Jednym z takich biomarkerów jest
BNP, którego oznaczanie u chorych z niewydolnością serca (HF, heart failure) jest rekomendowane przez Europejskie Towarzystwo Kardiologiczne (ESC, European Society of Cardiology) [17].

\section{Najczęściej występujące NP}

Wszystkie dotychczas poznane NP występują w organizmie człowieka. Najwyższe stężenie w osoczu osiąga ANP - 10 \pm 0,9 pM, którego okres półtrwania wynosi około 2 minut. Drugim co do częstości występowania jest CNP, którego stężenie w osoczu sięga 1,4 $\pm 0,6$ pM, natomiast okres półtrwania wynosi około 3 minut. Peptyd natriuretyczny typu B osiąga w osoczu stężenie $1 \pm 0,7$ pM, natomiast jego okres półtrwania to około 20 minut [18]. Stężenia powyższych NP ulegają różnym zmianom w przebiegu takich chorób, jak zastoinowa niewydolność krążenia czy przewlekła niewydolność nerek [19]. Urodylatyna i DNP występują w osoczu w śladowych ilościach [18].

\section{Miejsce biosyntezy NP}

Biosynteza poszczególnych NP odbywa się w różnych tkankach.

Przedsionkowy peptyd natriuretyczny jest cyklicznym polipeptydem zbudowanym z 28 aminokwasów. Peptyd ten jest wydzielany przede wszystkim przez kardiomiocyty przedsionków serca. Genem ANP jest NPPA (natriuretic peptide precursor A gene). Produkt NPPA to preproANP, który ulega modyfikacji posttranslacyjnej do proANP, a ten z kolei jest magazynowany w ziarnistościach wydzielniczych kardiomiocytów przedsionków. Po wydzieleniu z komórki proANP ulega proteolizie przy udziale koryny (proteaza serynowa), w efekcie czego powstaje biologicznie aktywny ANP. Wspomniana koryna odszczepia N-końcowy fragment cząsteczki zwany N-końcowym fragmentem proprzedsionkowego peptydu natriuretycznego (NT-proANP, N-terminal proatrial natriuretic peptide) [20]. Z NT-pro-ANP powstają trzy inne biologicznie aktywne peptydy: długodziałający peptyd natriuretyczny (LANP, long acting natriuretic peptide), peptyd kaliuretyczny (kaliuretic peptide) oraz peptyd rozszerzający naczynia (vessel dilator) (ryc. 1) [21, 22].

Bodźcem do wydzielania ANP przez kardiomiocyty przedsionków serca jest rozciągnięcie ich ścian pod wpływem wzrostu ciśnienia oraz zwiększenie częstości skurczów serca, a w szczególności skurczów przedsionków [23]. Uwalnianie ANP wzrasta również w stanach hipoksji, hipernatremii, a także pod wpływem katecholamin, endoteliny 1, angiotensyny II, wazopresyny, czynnika martwicy nowotworów alfa (TNF- $\alpha$, tumor necrosis factor alpha), prostaglandyny $\mathrm{F} 2 \alpha$ oraz witaminy $\mathrm{D}_{3}$. Tlenek azotu zmniejsza wydzielanie ANP [18].

Urodylatynę uważa się za wydzielany przez nerki produkt degradacji ANP o działaniu diuretycznym (jest to homolog 


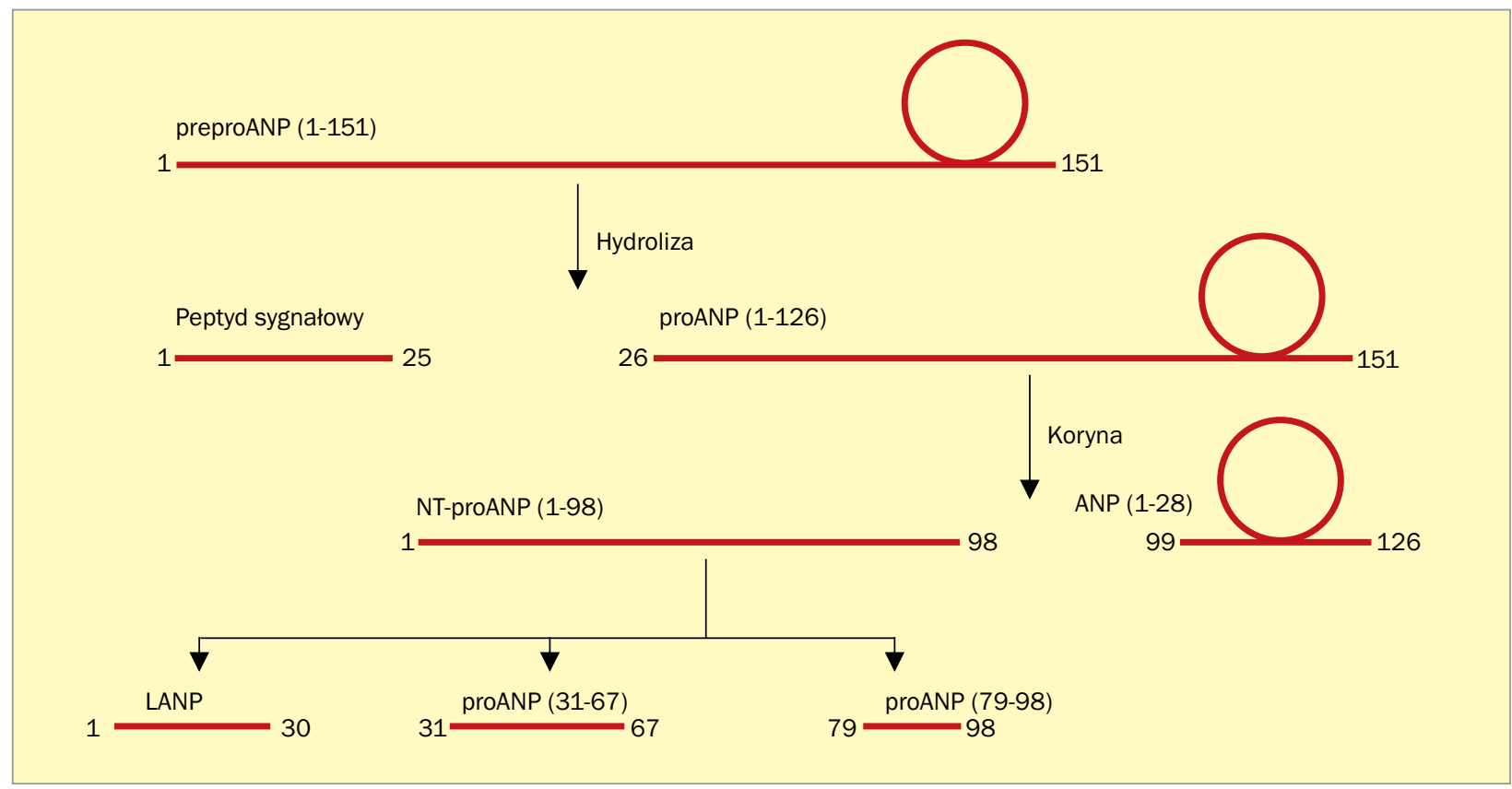

Rycina 1. Synteza przedsionkowego peptydu natriuretycznego (ANP, atrial natriuretic peptide); proANP (proatrial natriuretic peptide) proprzedsionkowy peptyd natriuretyczny; NT-proANP (N-terminal proatrial natriuretic peptide) - N-końcowy fragment proprzedsionkowego peptydu natriuretycznego; LANP (long acting natriuretic peptide) - długodziałający peptyd natriuretyczny

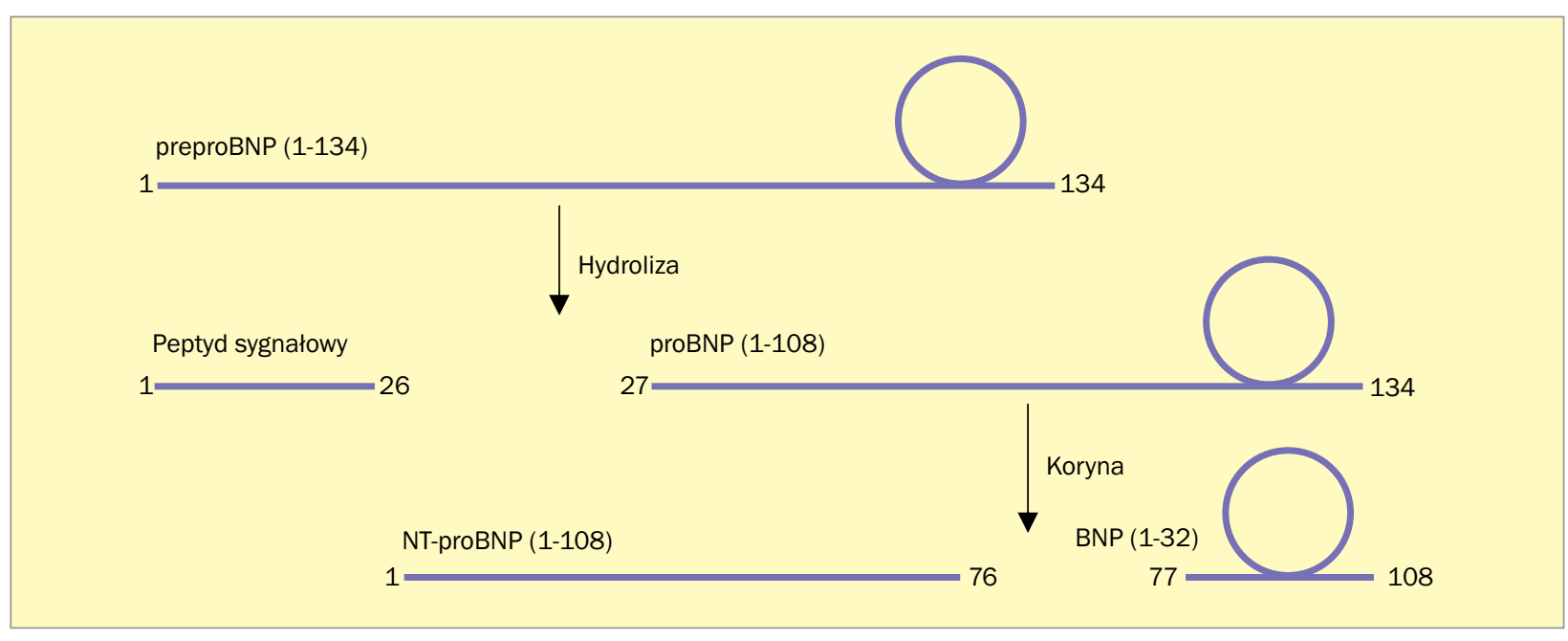

Rycina 2. Synteza peptydu natriuretycznego typu B (BNP, B-type natriuretic peptide); NT-proBNP (N-terminal pro-B-type natriuretic peptide) - N-końcowy fragment propeptydu natriuretycznego typu $B$

ANP krótszy o 4 aminokwasy). Powstaje w kanalikach dystalnych i zbiorczych nefronów w odpowiedzi na wzrost ciśnienia i objętości krwi [24].

Peptyd natriuretyczny typu B jest wydzielany przede wszystkim przez kardiomiocyty komór serca oraz komórki ośrodkowego układu nerwowego (OUN). Zbudowany jest z 32 aminokwasów. Ludzki gen BNP to NPPB (natriuretic peptide precursor $B$ gene). Z preproBNP pod wpływem proteazy serynowej powstaje proBNP, który z kolei przy udziale enzymu koryny zostaje przekształcony w aktywny biologicznie BNP [25]. Podczas powstawania BNP jako produkt uboczny powstaje N-końcowy fragment propeptydu natriuretycznego typu B (NT-proBNP, N-terminal proB-type natriuretic peptide) (ryc. 2).

Bezpośrednim stymulatorem do wydzielania BNP jest wzrost ciśnienia w komorach mięśnia sercowego, które zwiększa ekspresję genu tego peptydu. W warunkach doświadczalnych wykazano, że endotelina 1 zwiększa 


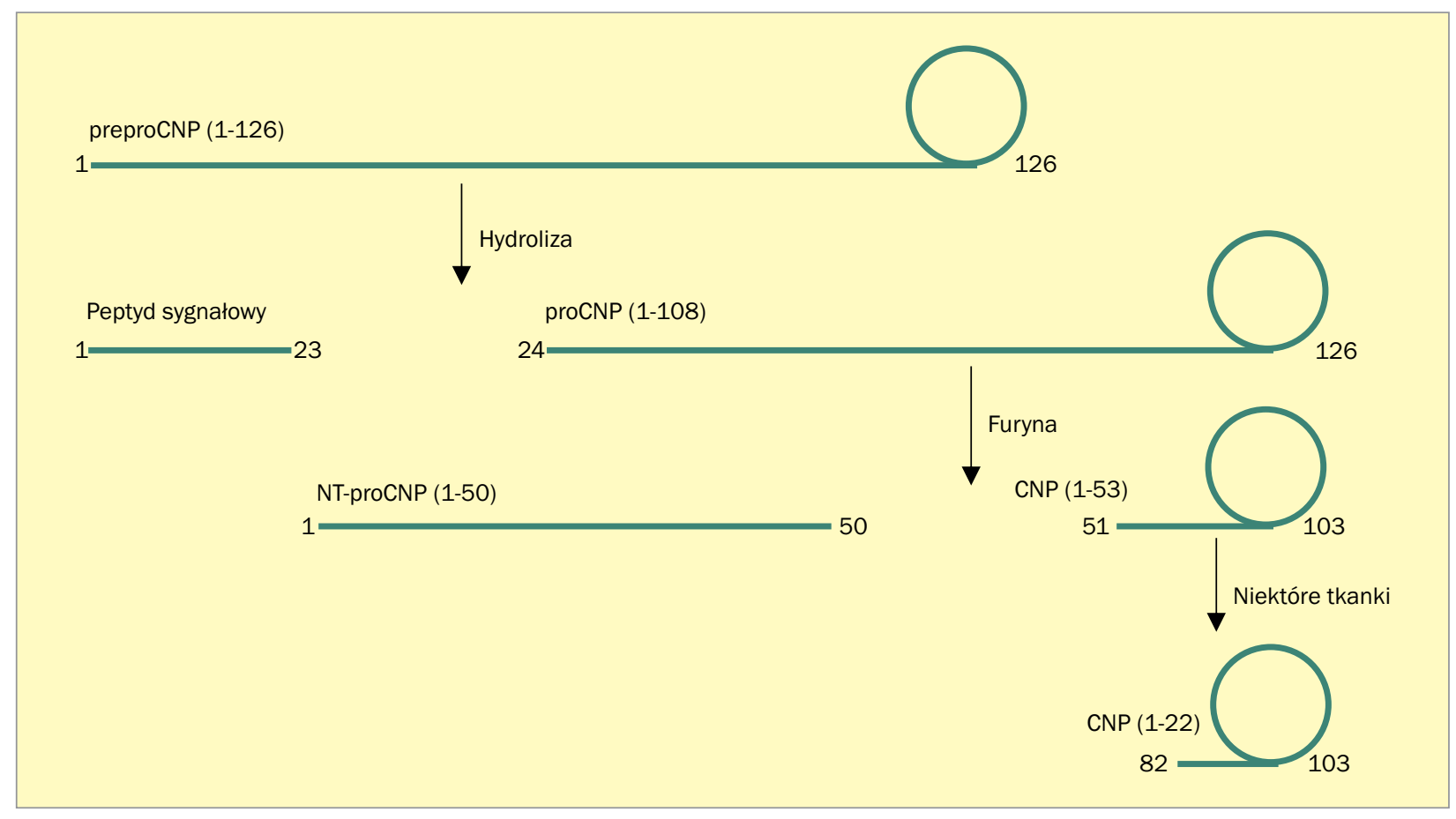

Rycina 3. Synteza peptydu natriuretycznego typu C (CNP, C-type natriuretic peptide); NT-proCNP (N-terminal pro-C-type natriuretic peptide) - N-końcowy fragment propeptydu natriuretycznego typu C

wydzielanie BNP w sercach szczurów [18]. Katabolizm BNP odbywa się przy udziale enzymów, takich jak dipeptydylo-peptydaza IV (DPP-IV, dipeptidyl-peptidase-IV), neprylizyny oraz enzymu rozkładającego insulinę (IDE, insulin-degrading enzyme). Dipeptydylo-peptydaza IV degraduje również NT-proBNP [26].

Peptyd natriuretyczny typu C produkują komórki OUN, śródbłonka naczyniowego, serca, nerek, nadnerczy oraz chondrocyty [27]. Pierwotnie powstaje jako preproCNP, który w wyniku działania proteazy serynowej jest przekształcany do proCNP. Następnie wewnątrzkomórkowy enzym furyna (endopeptydaza) odcina N-końcowy fragment (NT-proCNP, N-terminal pro-C-type natriuretic peptide), w wyniku czego powstaje aktywny biologiczne CNP 1-53. W niektórych tkankach z CNP 1-53 powstaje CNP 1-22. Obie formy CNP są aktywne biologicznie, lecz różnią się miejscem występowania: CNP 1-53 występuje głównie w mózgu, komórkach śródbłonka naczyniowego i sercu, natomiast CNP 1-22 w osoczu i płynie mózgowo-rdzeniowym [19] (ryc. 3).

Głównym czynnikiem stymulującym uwalnianie CNP przez komórki śródbłonka naczyniowego jest tak zwany stres ścinający (shear stress) będący nagłym wahnięciem ciśnienia tętniczego. W warunkach doświadczalnych zwiększenie uwalniania CNP przez komórki śródbłonka naczyniowego obserwuje się pod wpływem bradykininy, TNF- $\alpha$, interleukiny $1 \alpha$, interleukiny $1 \beta$, lipopolisacharydów, a także ANP i BNP $[18,19]$.
Peptyd natriuretyczny typu D w organizmie człowieka występuje w śladowych ilościach w miokardium i osoczu krwi [28].

Uroguanylina w postaci prouroguanyliny jest syntetyzowana głównie przez enterocyty. Główny bodziec do jej wydzielania to doustne spożycie pokarmów zawierających sód [29].

Osteokryna i muskulina są wydzielane przez komórki kości (osteoblasty i młode osteocyty) i mięśni szkieletowych $[3,4]$.

\section{Mechanizm działania NP}

Peptydy natriuretyczne realizują swoje funkcje poprzez oddziaływanie z receptorami błonowymi. Dotychczas zidentyfikowano i opisano trzy typy receptorów NP (tab. 1) $[18,19,30]$.

Receptory błonowe NPR-A oraz NPR-B składają się z domeny pozakomórkowej łączącej NP, domeny przezbłonowej oraz domeny wewnątrzkomórkowej, która aktywuje cyklaze guanylową (GC, guanylate cyclase). Powstający w wyniku działania GC cykliczny guanozynomonofosforan (cGMP, cyclic guanosine monophosphate) jest wtórnym przekaźnikiem aktywującym kinazę białkową G (PKG, protein kinase G). Pobudzenie PKG prowadzi do aktywacji szlaków biochemicznych, których efektem działania jest regulacja funkcjonowania układu krążenia. Receptor NPR-C, który nie jest związany z GC, odpowiada za internalizację i degradację NP wewnątrz 
Tabela 1. Charakterystyka receptorów peptydów natriuretycznych (opracowano na podstawie [19, 20, 30])

\begin{tabular}{|c|c|c|c|}
\hline Charakterystyka & NPR-A & NPR-B & NPR-C \\
\hline Typ receptora & Błonowy, sprzężony z GC & Błonowy, sprzężony z GC & Błonowy \\
\hline Powinowactwo NP & ANP $\geq$ BNP $>>C N P$ & CNP $>>$ ANP $\geq$ BNP & ANP $\geq$ CNP $>$ BNP \\
\hline Miejsce występowania & $\begin{array}{l}\text { Nerki, nadnercza, mózg, serce, } \\
\text { naczynia krwionośne, mięśnie gład- } \\
\text { kie, płuca, jelita, tkanka tłuszczowa }\end{array}$ & $\begin{array}{c}\text { Nerki, nadnercza, mózg, serce, } \\
\text { duże naczynia krwionośne, mięśnie } \\
\text { gładkie, płuca, chondrocyty, skóra, } \\
\text { macica }\end{array}$ & Większość tkanek \\
\hline Funkcja & $\begin{array}{l}\text { Rozszerzanie naczyń, natriureza, } \\
\text { zmniejszenie syntezy aldosteronu }\end{array}$ & Regulacja neurohormonów & $\begin{array}{l}\text { Usuwanie krążących NP } \\
\text { i kontrola miejscowych } \\
\text { efektów układu NP }\end{array}$ \\
\hline
\end{tabular}

NPR-A (natriuretic peptide repe peptide) - peptyd natriuretyczny typu B; CNP (C-type natriuretic peptide) - peptyd natriuretyczny typu C; NP (natriuretic peptides) - peptydy natriuretyczne

komórki (w lizosomie). Degradacja NP jest również katalizowana przez neprylizynę (NEP, neutral endopeptidase) występującą w postaci rozpuszczonej w osoczu oraz związanej z błoną komórkową. Enzym NEP podlega różnym mechanizmom regulatorowym - między innymi jest hamowany przez podwyższone stężenie BNP w osoczu. Neprylizyna poza katabolizmem NP bierze również udział w metabolizmie takich związków, jak endotelina 1, bradykinina, adrenomedulina oraz substancja P [23]. Co ważne, NEP katalizuje również reakcje przekształcenia angiotensyny I oraz angiotensyny 1-9 w angiotensyne 1-7. Angiotensyna 1-7 poprzez receptor Mas korzystnie wpływa na układ krążenia [26].

Receptor NPR-C oraz enzym NEP biorą zatem udział w regulacji biodostępności NP. Peptydy natriuretyczne są związkami działającymi w mechanizmie parakrynnym lub endokrynnym. Efektem ich działania jest regulacja objętości płynu pozakomórkowego (ECF, extracellular fluid) oraz ciśnienia tętniczego (BP, blood pressure) poprzez zwiększanie natriurezy i diurezy, hamowanie układu renina-angiotensyna-aldosteron (RAA), aktywności współczulnej oraz wydzielania hormonu antydiuretycznego (ADH, antidiuretic hormone) i adrenokortykotropiny (ACTH, adrenocorticotropic hormone), zmniejszanie pragnienia, rozszerzenie naczyń [30]. Mechanizm działania i metabolizm NP przedstawiono na rycinie 4.

\section{Znaczenie NP w fizjologii i patologii człowieka}

Odkrycie NP doprowadziło do rozwoju wiedzy na temat funkcjonowania układu krążenia. Nieprawidłowości związane z NP początkowo dotyczyły dwóch schorzeń - nadciśnienia tętniczego oraz HF [31, 32]. Dalsze badania nad biochemią i fizjologią NP doprowadziły do poznania kolejnych molekularnych mechanizmów ich działania, a także umożliwiły dokładniejsze poznanie patogenezy innych CVD $[33,34]$.

\section{Przedsionkowy peptyd natriuretyczny i URO} Działanie ANP jest wielokierunkowe i dotyczy głównie regulacji funkcji układu krążenia oraz czynności nerek. W układzie krążenia ANP reguluje odpowiedź z baroreceptorów i zmniejsza pobudzenie współczulnego układu nerwowego. Ponadto efektem działania ANP jest rozkurcz mięśni gładkich naczyń krwionośnych na skutek zwiększenia aktywności syntazy tlenku azotu zależnej od jonów wapnia i kalmoduliny. Poprzez zwiększenie przepuszczalności śródbłonka naczyniowego ANP reguluje objętość płynu wewnątrzkomórkowego. W ostatnim czasie dowiedziono, że ANP zmniejsza przerost mięśnia sercowego. Ogranicza również jego włóknienie [34]. Mechanizm działania ANP w nerkach prowadzi do nasilenia diurezy i natriurezy. Aby osiągnąć wspomniane efekty, ANP oddziałuje na wiele czynników. Po pierwsze wiadomo, że ANP - zwiększając przepuszczalność naczyń w kłębuszku nerkowym - zwiększa przesączanie kłębuszkowe (GFR, glomerular filtration rate). Peptyd natriuretyczny typu A ogranicza efekty działania układu RAA poprzez zmniejszanie aktywności błonowej ATP-azy $\mathrm{Na}^{+} / \mathrm{K}^{+}$, zmniejszanie aktywności kotransportera $\mathrm{Na}^{+}-\mathrm{K}^{+}-2 \mathrm{Cl}^{-}(\mathrm{NKCC} 2)$ w ramieniu wstępującym pętli Henlego oraz zmniejszenie aktywności kanałów kationowych bramkowanych nukleotydami cyklicznymi i nabłonkowych kanałów sodowych (ENaC, epithelial sodium channels), a także kanałów związanych z receptorami przejściowego potencjału (TRPV4, transient receptor potential cation channel subfamily $V$ member 4 ) w kanaliku zbiorczym nerki [34, 35]. Zmniejszenie efektów działania aldosteronu może być również efektem tego, że ANP zmniejsza wydzielanie ACTH przez przysadkę mózgową, która w pewnym, ograniczonym, stopniu pobudza wydzielanie tego mineralokortykoidu przez warstwę kłębkowatą kory nadnerczy [36]. Nasilenie diurezy jest również efektem zmniejszania uwalniania ADH przez tylny płat przysadki mózgowej [37].

W badaniach eksperymentalnych dowiedziono, że brak genu ANP (NPPA) lub NPR-A prowadzi do nadciśnienia 


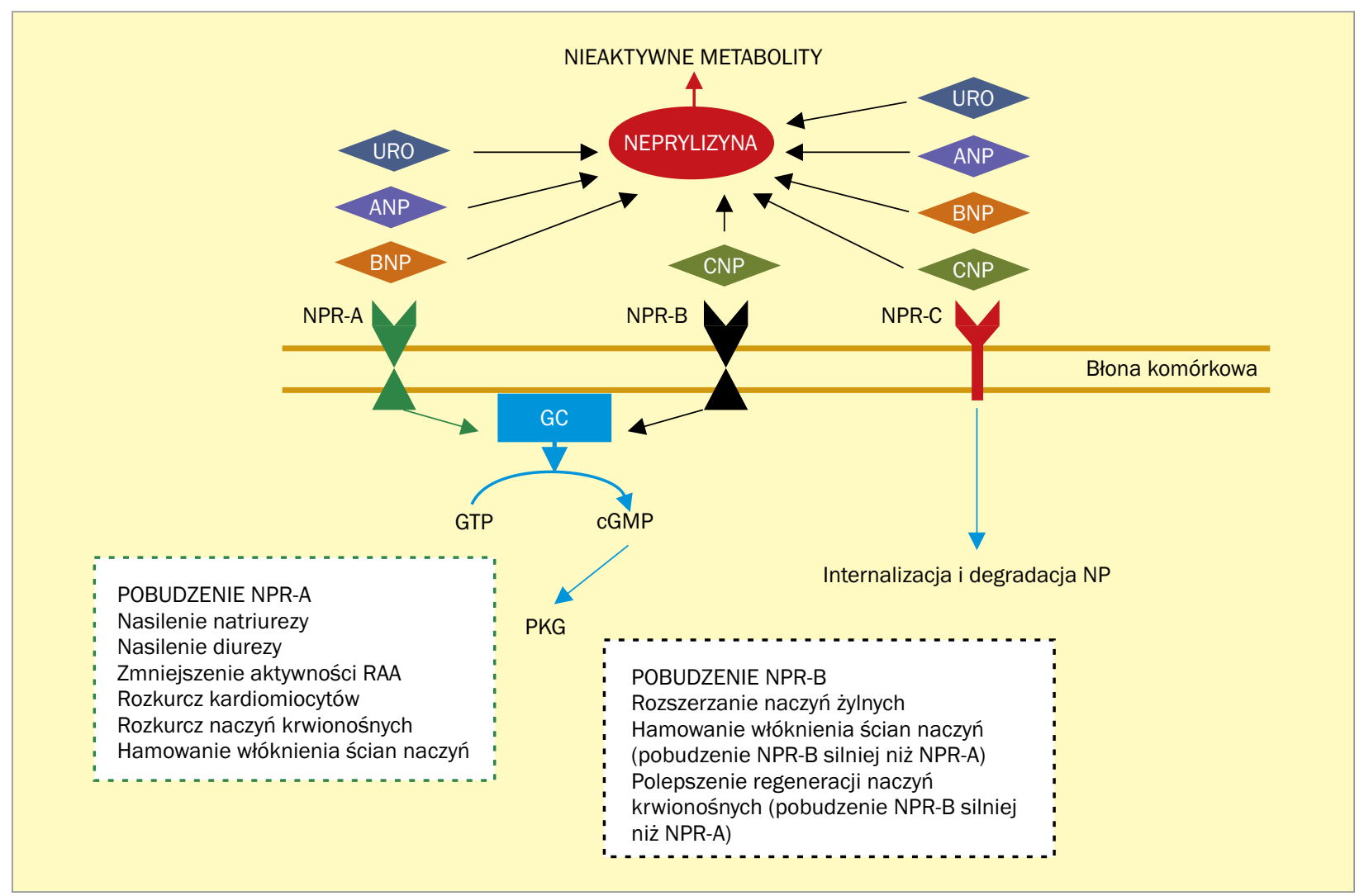

Rycina 4. Mechanizm działania peptydów natriuretycznych; URO (urodilatin) - urodylatyna; ANP (atrial natriuretic peptide) - przedsionkowy peptyd natriuretyczny; BNP (B-type natriuretic peptide) - peptyd natriuretyczny typu B; CNP (C-type natriuretic peptide) - peptyd natriuretyczny typu C; NPR-A (natriuretic peptide receptor type A) - receptor typu A peptydów natriuretycznych; NPR-B (natriuretic peptide receptor type B) - receptor typu B peptydów natriuretycznych; NPR-C (natriuretic peptide receptor type C) - receptor typu C peptydów natriuretycznych; GC (guanylate cyclase) - cyklaza guanylowa; GTP (guanosine triphosphate) - guanozynotrifosforan; cGMP (cyclic guanosine monophosphate) - cykliczny guanozynomonofosforan; PKG (protein kinase G) - kinaza białkowa G; NP (natriuretic peptides) - peptydy natriuretyczne; RAA - układ renina-angiotensyna-aldosteron

tętniczego i wiąże się z przerostem mięśnia sercowego, który jest niezależny od wartości BP [38]. Ponadto udowodniono, że brak NPR-A doprowadza do sodowrażliwego nadciśnienia tętniczego, natomiast duplikacja tego genu skutkuje ochroną przed wysoką zawartością soli w diecie $[39,40]$. Peptydy natriuretyczne kontrolują metabolizm lipidów poprzez efekt antylipolityczny [41]. Warto zauważyć, że promują biogenezę mitochondriów w adipocytach i proces „brązowienia” białych adipocytów [42]. Wspomniany efekt antylipolityczny wiąże się ze zmniejszeniem przez ANP aktywności proproteinowej konwertazy subtilizyny/ /kexiny typu 9 (PCSK9, proprotein convertase subtilisin/ /kexin type 9) [43], która jest odpowiedzialna za degradację receptora lipoprotein o małej gęstości (LDL-R, low-density lipoprotein receptor) w hepatocytach [44]. Przedsionkowy peptyd natriuretyczny, zmniejszając aktywność PCSK9, prowadzi do zwiększenia liczby receptorów LDL na powierzchni błony hepatocytów, co skutkuje wydajniejszym wychwytywaniem LDL z krążenia [45]. Podobną strategię działania wykazują nowe leki normolipemizujące, takie jak ewolokumab i alirokumab [46]. W przyszłości interesujące mogą się okazać obserwacje chorych stosujących leki z grupy antagonistów receptora $\mathrm{AT}_{1}$ dla angiotensyny II i inhibitora neprylizyny (ARNI, angiotensin receptor neprilysin inhibitor) w kontekście stężenia cholesterolu frakcji LDL [47].

Proproteinowa konwertaza subtilizyny/kexiny typu 6 (PCSK6, proprotein convertase subtilisin/kexin type 6) jest proteazą serynową. Mutacja genu PCSK6 prowadzi do rozwoju zależnego od sodu nadciśnienia tętniczego. Proteaza ta jest aktywatorem enzymu koryny. Koryna to transbłonowa proteaza serynowa zaangażowana w aktywację ANP. W kardiomiocytach forma prekursorowa ANP - pro-ANP - jest cięta przez korynę w celu wytworzenia ANP. W badaniach eksperymentalnych wykazano, że zastosowanie benzamidyny (inhibitor PCSK6) prowadzi do zahamowania aktywacji koryny. Wtórny niedobór aktywnej formy ANP powoduje wzrost natremii oraz BP [48].

Urodylatyna bierze udział w regulacji gospodarki wodno-elektrolitowej. W przeciwieństwie do ANP charakteryzuje się wyłącznie parakrynnym mechanizmem działania. 
W sytuacji wzrostu ciśnienia i objętości krwi URO nasila diurezę poprzez zwiększenie przepływu krwi przez nerki [27].

\section{Peptyd natriuretyczny typu B}

Fizjologiczna rola BNP jest słabiej poznana niż ANP. Wyniki badań wskazują, że BNP bierze udział w zmniejszaniu produkcji i akumulacji kolagenu, poprzez co ogranicza włóknienie i przebudowę ścian komór serca. Ponadto BNP wykazuje działanie rozkurczowe względem kardiomiocytów komór. Podobnie jak ANP, BNP zmniejsza efekty działania układu RAA, ograniczając wazokonstrykcję naczyń krwionośnych, retencji sodu i wody przez nerki [49].

\section{Peptyd natriuretyczny typu C}

Wpływ tego NP na układ krążenia jest stosunkowo mało znany. Wykazuje zarówno działania parakrynne, jak i endokrynne. Główna fizjologiczna rola CNP to stymulacja rozwoju kości długich poprzez wpływ na funkcje chondrocytów. Wykazano, że defekty genetyczne związane z genem CNP objawiają się karłowatością. Zwiększona ekspresja genu CNP prowadzi do przerostu kośćca $[18,19]$.

Efekt diuretyczny wywoływany przez CNP jest niewielki mimo faktu, że w nerkach są zlokalizowane receptory NPR-B. Znacznie bardziej istotny wpływ CNP wywiera na układ krążenia. Dzięki zmniejszaniu proliferacji, włóknienia, syntezy kolagenu oraz namnażania fibroblastów i miocytów peptyd ten bierze również istotny udział w regeneracji komórek śródbłonka naczyniowego. Wykazano również, że CNP ma właściwości przeciwpłytkowe. Poprzez receptor NPR-C zmniejsza agregację płytek krwi [50].

\section{Peptyd natriuretyczny typu D}

Ze względu na śladowe ilości DNP w organizmie człowieka jego rola fizjologiczna nie jest w pełni poznana [18].

\section{Uroguanylina}

Uroguanylina jest NP uczestniczącym w wielu procesach fizjologicznych. Peptyd ten działa zarówno w mechanizmie endokrynnym, jak i parakrynnym. Wydzielona uroguanylina dostaje się z prądem krwi do nerek, gdzie w mechanizmie zależnym i niezależnym od GC nasila natriurezę. Wyniki badań ostatnich lat sugerują również udział uroguanyliny w regulacji odczucia apetytu poprzez oddziaływanie z receptorem GUCY2C w podwzgórzu. Efektem działania uroguanyliny w podwzgórzu jest uczucie sytości [51, 52]. Wyniki badań eksperymentalnych na myszach z brakiem genu uroguanyliny, wykazały, że zwierzęta te mają znacznie wyższe BP niż zwierzęta typu dzikiego, które wiązało się ze zmniejszonym wydalaniem sodu przez nerki [53]. Badania kliniczne dostarczyły pewnych dowodów na rolę uroguanyliny w HF i niewydolności nerek [51].

\section{Osteokryna i muskulina}

Osteokryna i muskulina nie regulują bezpośrednio gospodarki wodno-elektrolitowej. Osteokryna bierze udział w regulacji działania witaminy $D_{3}$, natomiast muskulina jest zaangażowana w metabolizm glukozy [3, 4]. W badaniach eksperymentalnych wykazano, że OSTN obniża stężenie osteokalcyny i fosfatazy alkalicznej, przyczyniając się do zmniejszenia mineralizacji kości. Witamina $\mathrm{D}_{3}$ zmniejsza ekspresję genu OSTN [54]. Wykazano, że OSTN, łącząc się z NPR-C, zwiększa biodostępność NP, przez co może ograniczać pogorszenie HF po zawale serca [54]. U otyłych myszy stwierdzono wzrost stężenia muskuliny. Muskulina osłabia działanie insuliny, co może prowadzić do rozwoju insulinooporności tkanek [4].

Doniesienia z ostatnich lat wskazują na istotną rolę NP w przebudowie układu krążenia. Efekty komórkowe działania NP dotyczą zarówno komórek mięśnia sercowego jak i komórek naczyń krwionośnych i obejmują procesy takie jak proliferacja, angiogeneza, apoptoza, zwłóknienie oraz zapalenie tych komórek [1].

\section{Peptydy natriuretyczne \\ w diagnostyce kardiologicznej}

Przedsionkowy peptyd natriuretyczny, ze względu na krótszy okres półtrwania i większą labilność w porównaniu z BNP, nie jest rutynowo wykorzystywany jako biomarker HF. Niedawno opisany środkowo-regionalny przedsionkowy propeptyd natriuretyczny (MR-proANP, midregional pro-atrial natriuretic peptide) cechuje się większą stabilnością i może się okazać bardziej obiecującym biomarkerem niż ANP [55]. Powstaje on podczas przekształcenia preproANP do ANP. Obecnie pomiar MR-proANP w osoczu jest traktowany na równi z oznaczaniem BNP i NT-proBNP na liście biomarkerów, których oznaczanie rekomenduje ESC [17].

W licznych badaniach wykazano, że stężenie BNP i NT-proBNP ma wartość diagnostyczną i prognostyczną w HF, dlatego też w najnowszych wytycznych ESC zaleca się wykonywanie oznaczeń BNP i NT-proBNP u chorych z podejrzeniem tego schorzenia. Warto wspomnieć, że HF to przewlekły zespół chorobowy, skutkujący poważnym rokowaniem oraz konsekwencjami społecznymi i ekonomicznymi. W Polsce na HF choruje 600-700 tys. osób, natomiast zachorowalność w populacji ogólnej wynosi około 2,6\% [56, 57].

W zależności od występujących objawów klinicznych oraz stężeń BNP i NT-proBNP zaleca się wykonanie dodatkowych badań. Należy pamiętać o innych sytuacjach klinicznych, w przebiegu których dochodzi do zmian stężeń NP (tab. 2) [58, 59].

W sytuacji braku objawów HF ze wspótistniejącym stężeniem BNP większym lub równym $35 \mathrm{pg} / \mathrm{ml}$ i NT-proBNP większym lub równym $125 \mathrm{ng} / \mathrm{ml}$ w wytycznych ESC wskazuje się na konieczność wykonania badania echokardiograficznego. Stężenia BNP i NT-proBNP jest również istotne z punktu widzenia terapeutycznego. $U$ chorych z przewlekła niewydolnością serca i obniżoną frakcją wyrzutową lewej komory, którzy stosują $\beta$-adrenolityk i inhibitor konwertazy angiotensyny (ACE, angiotensin-converting enzyme), 
Tabela 2. Sytuacje kliniczne wpływające na stężenie peptydów natriuretycznych (NP, natriuretic peptides) w osoczu krwi (opracowano na podstawie $[58,59])$

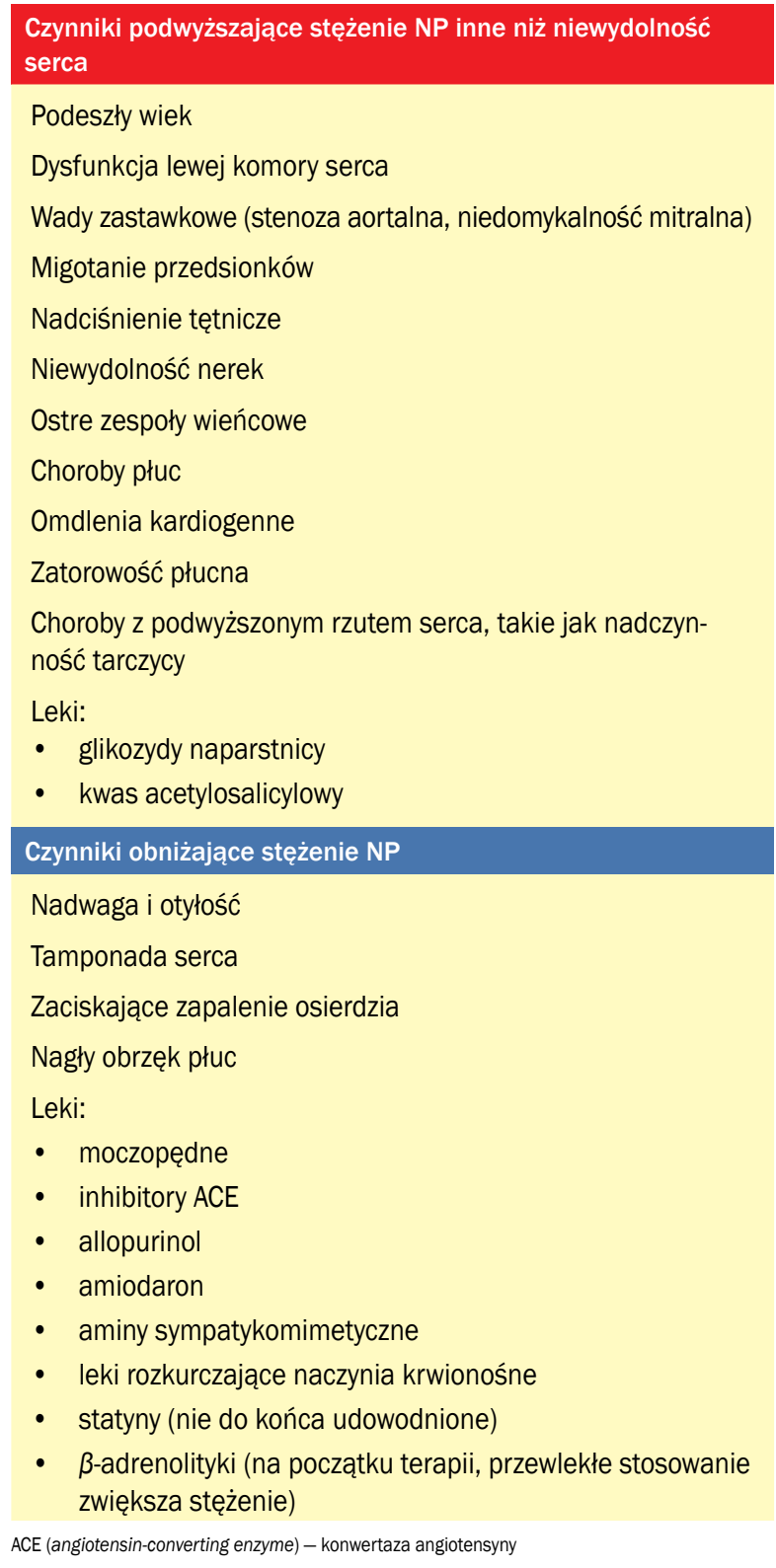

należy dodać antagonistę aldosteronu (spironolakton, eplerenon), jeśli stężenie BNP przekracza 250 pg/ml lub NT-proBNP wynosi ponad $500 \mathrm{pg} / \mathrm{ml}$ u mężczyzn i ponad 750 pg/ml u kobiet. W wytycznych ESC wskazuje się, że w sytuacji nadal utrzymujących się objawów HF u chorych leczonych $\beta$-adrenolitykiem, inhibitorem ACE i antagonistą aldosteronu należy włączyć sakubitryl/walsartan zamiast inhibitora ACE. Określenie stężeń BNP i NT-proBNP jest również zalecane w algorytmie diagnostycznym ostrej HF. U chorych z dusznością i podejrzeniem ostrej HF, u których stężenie BNP wynosi mniej niż 100 pg/ml, NT-proBNP mniej niż 300 pg/ml oraz MR-proANP poniżej 120 pg/ml, rozpoznanie tego stanu jest mało prawdopodobne [17, 37].
Warto również wspomnieć, że obniżenie stężeń NT-proBNP i BNP u chorych z HF wskazuje na poprawę czynności serca dzięki podjętym interwencjom. Niewydolność serca często wiąże się z migotaniem przedsionków, które samo w sobie występuje $z$ wyższymi stężeniami BNP [60, 61]. Wartość BNP może się nie różnić między chorymi z HF i migotaniem przedsionków a chorymi z HF bez migotania przedsionków [62]. W praktyce klinicznej należy wziąć pod uwage wyższe poziomy BNP, aby poprawić specyficzność i prawdopodobieństwo prawidłowego rozpoznania HF u osoby z migotaniem przedsionków [63].

Stężenia BNP i NT-proBNP mogą również posłużyć w ocenie ryzyka zgonu z powodu HF (BCN Bio-HF, kalkulator ryzyka Barcelona Bio-Heart Failure Risk Calculator) [17, 61].

\section{Peptydy natriuretyczne jako leki}

Korzystne efekty działania NP sprawiły, że zaczęto je badać jako potencjalne leki w terapii CVD. Nezyrytyd (nesiritid) jest rekombinowanym ludzkim BNP. Lek ten łagodzi objawy związane z zastojem w krążeniu płucnym oraz rozszerza naczynia tętnicze i żylne, zmniejszając wstępne obciążenie serca (preload). Wykazano, że nezyrytyd w połączeniu z konwencjonalnym leczeniem lekiem moczopędnym powoduje istotne zmniejszenie duszności [64]. Wskazaniem do stosowania nezyrytydu jest zaostrzenie zastoinowej HF z objawami duszności spoczynkowej lub podczas niewielkiej aktywności (klasa III-IV wg NYHA). W Stanach Zjednoczonych od 2001 roku zatwierdzono nezyrytyd do leczenia ostrej zdekompensowanej HF. W ostrej HF stosuje się również ludzki rekombinowany ANP (carperetid). Istotnym problemem w wykorzystaniu carperetydu jest konieczność jego ciągłej infuzji ze względu na krótki okres półtrwania [65]. Połączenie CNP i 15-aminokwasowego C-końcowego fragmentu DNP (cenderitide) jest oporne na degradację enzymatyczną [66]. Trwają prace nad analogiem ANP (MANP) będącym 40-aminokwasowym peptydem z 12-aminokwasowym przedłużeniem końca karboksylowego ANP [36]; MANP jest bardziej oporny na degradację niż endogenny ANP. Związek ten przebadano zarówno w warunkach eksperymentalnych, jak i klinicznych, uzyskując dowody efektu przeciwnadciśnieniowego. Trwają dalsze badania nad bezpieczeństwem terapii i innych korzystnych efektów działania MANP [67]. Warto wspomnieć, że w badaniach klinicznych I i ll fazy potwierdzono korzystne efekty działania syntetycznej URO (ularitide) [68].

Rekombinowane ludzkie NP obecnie nie mają w Polsce rejestracji.

Poznanie efektów działania NP doprowadziło do opracowania ARNI, czyli leku będącego połączeniem inhibitora NEP (sakubitryl) oraz inhibitora receptora typu 1 dla angiotensyny II (walsartan). Zmniejszanie aktywności NEP skutkuje $z$ jednej strony zwiększeniem biodostępności NP, a z drugiej strony zmniejsza ilość angiotensyny 1-7. 


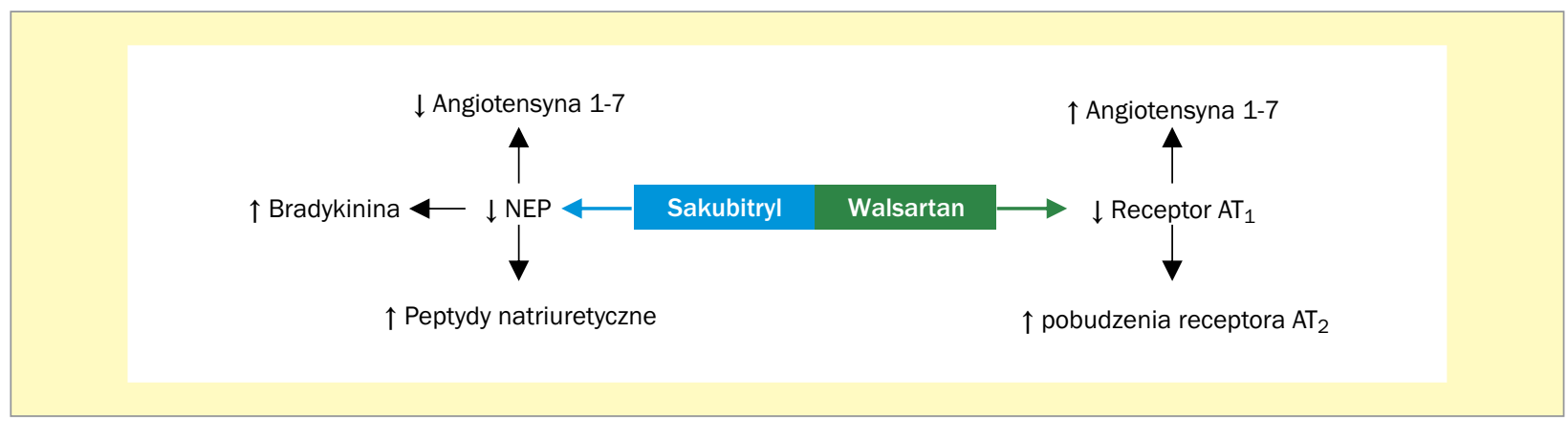

Rycina 5. Mechanizm działania sakubitrylu i walsartanu; NEP - neprylizyna

Walsartan z kolei zmniejsza aktywność receptora $\mathrm{AT}_{1}$, zwiększa ilość wytwarzanej angiotensyny 1-7 oraz zwiększa pobudzenie receptora $\mathrm{AT}_{2}$ (ryc. 5) [17, 41]. Wskazaniem do stosowania ARNI jest objawowa, przewlekła HF ze zmniejszoną frakcją wyrzutową.

Obecnie w Polsce jest dostępny preparat zawierający w jednej tabletce sakubitryl i walsartan.

Valentino i wsp. sugerują [51], że w przyszłości uroguanylina może być wykorzystana w leczeniu otyłości.

\section{Podsumowanie}

Zrozumienie mechanizmów działania NP w ostatnich latach doprowadziło do uznania tych hormonów peptydowych za istotny system regulujący czynność układu sercowo-naczyniowego i gospodarki wodno-elektrolitowej. Związki te nasilają diurezę i natriurezę oraz rozszerzają naczynia krwionośne. Ponadto badania ujawniły inne korzystne efekty działania NP, takie jak zmniejszanie włóknienia i proliferacji komórek. Nowe leki stosowane w CVD, takie jak ARNI, zwiększają biodostępność NP. Dokonano syntezy rekombinowanych NP w celu ich wykorzystywania w terapii CVD. W diagnostyce laboratoryjnej HF są wykorzystywane BNP i ANP jako najważniejsze NP.

\section{Konflikt interesów}

Autorzy deklarują brak konfliktu interesów.

\section{Abstract}

Natriuretic peptides (NP) are hormones mainly involved in the regulation of water and electrolyte balance and the regulation of cardiovascular function. So far, six classic NP have been described: type A natriuretic peptide, urodilatin, type $B$ natriuretic peptide, type $C$ natriuretic peptide, type $D$ natriuretic peptide and uroguanylin. The family of natriuretic peptides also includes osteocrin and musculin, which have different metabolic activities. NP carry out their biological activities by interacting with three membrane receptors. The bioavailability of these compounds is regulated, among others, by neprilisin. Plasma NP concentrations change during many diseases. The most important of these include heart failure (HF). The guidelines of the European Society of Cardiology indicate that the determination of plasma peptide concentrations levels is helpful in the diagnosis of HF.

Understanding the physiology of natiruretic peptides has led to the search for new drugs that would mimic their beneficial effects. In addition to the beneficial effects of natriuretic peptides on the cardiovascular system, it has been shown that these compounds are involved in the regulation of many other metabolic processes - among others in the regulation of the center of hunger and satiety in the hypothalamus.

The purpose of this work is to present the definitions, history, mechanisms of natiruretic peptides, as well as their role in human physiology and pathology and to present clinical issues related to these hormones.

Key words: natriuretic peptides, cardiovascular system, heart failure, cardiovascular diseases

Folia Cardiologica 2020; 15, 2: 137-148 


\section{Piśmiennictwo}

1. Rubattu S, Volpe M. Natriuretic peptides in the cardiovascular system: multifaceted roles in physiology, pathology and therapeutics. Int J Mol Sci. 2019; 20(16), doi: 10.3390/ijms20163991, indexed in Pubmed: 31426320.

2. Levin ER, Gardner DG, Samson WK. Natriuretic peptides. N Engl J Med. 1998; 339(5): 321-328, doi: 10.1056/NEJM199807303390507, indexed in Pubmed: 9682046.

3. Thomas G, Moffatt P, Salois P, et al. Osteocrin, a novel bone-specific secreted protein that modulates the osteoblast phenotype. J Biol Chem. 2003; 278(50): 50563-50571, doi: 10.1074/jbc. M307310200, indexed in Pubmed: 14523025.

4. Nishizawa H, Matsuda M, Yamada Y, et al. Musclin, a novel skeleta muscle-derived secretory factor. J Biol Chem. 2004; 279(19): 19391-19395, doi: 10.1074/jbc.C400066200, indexed in Pubmed: 15044443.

5. Potter LR, Abbey-Hosch S, Dickey DM. Natriuretic peptides, their receptors, and cyclic guanosine monophosphate-dependent signaling functions. Endocr Rev. 2006; 27(1): 47-72, doi: 10.1210/er.20050014, indexed in Pubmed: 16291870.

6. Kish B. Electron microscopy af the atrium of the heart. Exp Med Surg. 1956; 14: 99.

7. Jamieson JD, Palade GE. Specific granules in atrial muscle cels. J Cell Biol. 1964; 23: 151-172, doi: 10.1083/jcb.23.1.151, indexed in Pubmed: 14228508.

8. Genest J, de Bold AJ, Borenstein HB, et al. A rapid and potent natriuretic response to intravenous injection of atrial myocardial extract in rats. Life Sci. 1981; 28(1): 89-94, doi: 10.1016/0024-3205(81)90370-2, indexed in Pubmed: 7219045.

9. Lumsden NG, Khambata RS, Hobbs AJ. C-type natriuretic peptide (CNP): cardiovascular roles and potential as a therapeutic target. Curr Pharm Des. 2010; 16(37): 4080-4088, doi: 10.2174/138161210794519237, indexed in Pubmed: 21247399.

10. Schulz-Knappe P, Forssmann K, Herbst F, et al. Isolation and structural analysis of. Klin Wochenschr. 1988; 66(17): 752-759, doi: 10.1007/ /bf01726570, indexed in Pubmed: 2972874.

11. Schweitz $H$, Vigne $P$, Moinier D, et al. A new member of the natriuretic peptide family is present in the venom of the green mamba (Dendroaspis angusticeps). J Biol Chem. 1992; 267(20): 13928-13932, indexed in Pubmed: 1352773.

12. Yuge S. Chapter 23 - Guanylin family. In: Takei Y, Ando H, Tsutsui K, Hikaku N, Gakkai N. ed. Handbook of hormones: comparative endocrinology for basic and clinical research. Academic Press, Oxford 2016: 195-196.

13. Nichols M, Townsend N, Scarborough P, et al. Cardiovascular disease in Europe: epidemiological update. Eur Heart J. 2013; 34(39): 3028-3034, doi: 10.1093/eurheartj/eht356, indexed in Pubmed: 24014390.

14. Zdrojewski T, Solnica B, Cybulska B, et al. Prevalence of lipid abnormalities in Poland. The NATPOL 2011 survey. Kardiol Pol. 2016; 74(3): 213-223, doi: 10.5603/KP.2016.0029, indexed in Pubmed: 27004543.

15. Surma S, Szyndler A, Narkiewicz K. [Awareness of selected risk factors for cardiovascular disease in the young population] [Article in Polish] Choroby Serca i Naczyń. 2017; 14(4): 186.

16. Surma St, Szyndler A, Narkiewicz K. [Awareness of hypertension and other risk factors for cardiovascular disease in the adult population] [Article in Polish]. Choroby Serca i Naczyń. 2018; 15(1): 14-22.

17. Ponikowski P, Voors A, Anker S, et al. [2016 ESC Guidelines for the diagnosis and treatment of acute and chronic heart failure] [Article in Polish]. Kardiol Pol. 2016; 74(10): 1037-1147, doi: 10.5603/ /kp.2016.0141.

18. Nishikimi T, Kuwahara K, Nakao K. Current biochemistry, molecular biology, and clinical relevance of natriuretic peptides. J Cardiol. 2011; 57(2): 131-140, doi: 10.1016/j.jjcc.2011.01.002, indexed in Pubmed: 21296556.

19. Jerczyńska H, Pawłowska Z. Peptydy natriuretyczne - ich receptory i rola w układzie krążenia. Post Bioch. 2007; 54: 35-42.

20. Kerkelä R, Ulvila J, Magga J. Natriuretic peptides in the regulation of cardiovascular physiology and metabolic events. J Am Heart Assoc. 2015; 4(10): e002423, doi: 10.1161/JAHA.115.002423, indexed in Pubmed: 26508744.

21. Vesely DL, Perez-Lamboy GI, Schocken DD. Long-acting natriuretic peptide, vessel dilator, and kaliuretic peptide enhance the urinary excretion rate of beta2-microglobulin. Metabolism. 2000; 49(12): 1592-1597, doi: 10.1053/meta.2000.18557, indexed in Pubmed: 11145122.

22. Chen $\mathrm{HH}$, Burnett JC. Natriuretic peptides in the pathophysiology of congestive heart failure. Curr Cardiol Rep. 2000; 2(3): 198-205, doi: 10.1007/s11886-000-0069-3, indexed in Pubmed: 10980893.

23. Volpe M, Tocci G, Battistoni A, et al. Angiotensin II receptor blocker neprilysin inhibitor (ARNI): new avenues in cardiovascular therapy. High Blood Press Cardiovasc Prev. 2015; 22(3): 241-246, doi: 10.1007/ /s40292-015-0112-5, indexed in Pubmed: 26100410.

24. Stryjewski P, Nessler B, Cubera K, et al. Peptydy natriuretyczne. Historia odkrycia, budowa chemiczna, mechanizmdziałania oraz metabolizm. Podstawy zastosowania diagnostycznego i leczniczego. Przeg| Lek. 2013; 70: 463-467.

25. Szabó G. Biology of the B-type natriuretic peptide: structure, synthesis and processing. Biochem Anal Biochem. 2012; 1(8): 1000e129, doi: 10.4172/2161-1009.1000e129.

26. Favresse J, Gruson D. Natriuretic peptides: degradation, circulating forms, dosages and new therapeutic approaches. Ann Biol Clin (Paris). 2017; 75(3): 259-267, doi: 10.1684/abc.2017.1235, indexed in Pubmed: 28446390.

27. Potter LR, Yoder AR, Flora DR, et al. Natriuretic peptides: their structures, receptors, physiologic functions and therapeutic applications. Handb Exp Pharmacol. 2009(191): 341-366, doi: 10.1007/978-3540-68964-5_15, indexed in Pubmed: 19089336.

28. Pandit K, Mukhopadhyay P, Ghosh S, et al. Natriuretic peptides: diagnostic and therapeutic use. Indian J Endocrinol Metab. 2011; 15(Suppl 4): S345-S353, doi: 10.4103/2230-8210.86978, indexed in Pubmed: 22145138.

29. Rahbi $H$, Narayan $H$, Jones $D J L$, et al. The uroguanylin system and human disease. Clin Sci (Lond). 2012; 123(12): 659-668, doi: 10.1042/CS20120021, indexed in Pubmed: 22877138.

30. Mannu G, Bhalerao A. Advances in the mechanism of action of natriuretic peptides at a cellular level. BJMMR. 2015; 9(11): 1-15, doi: 10.9734/bjmmr/2015/19325.

31. Rubattu S, Sciarretta S, Valenti V, et al. Natriuretic peptides: an update on bioactivity, potential therapeutic use, and implication in cardiovascular diseases. Am J Hypertens. 2008; 21(7): 733-741, doi: 10.1038/ajh.2008.174, indexed in Pubmed: 18464748.

32. Volpe M, Rubattu S, Burnett J. Natriuretic peptides in cardiovascular diseases: current use and perspectives. Eur Heart J. 2014; 35(7): 419-425, doi: 10.1093/eurheartj/eht466, indexed in Pubmed: 24227810.

33. Das BB, Solinger R. Role of natriuretic peptide family in cardiovascular medicine. Cardiovasc Hematol Agents Med Chem. 2009; 7(1): 29-42, doi: 10.2174/187152509787047630, indexed in Pubmed: 19149542 
34. Kario K. The sacubitril/valsartan, a first-in-class, angiotensin receptor neprilysin inhibitor (ARNI): potential uses in hypertension, heart failure, and beyond. Curr Cardiol Rep. 2018; 20(1): 5, doi: 10.1007/ /s11886-018-0944-4, indexed in Pubmed: 29374807.

35. Surma S, Adamczak M, Więcek A. Hiponatremia spowodowana tiazydowymi i tiazydopodobnymi lekami moczopędnymi. Terapia. 2019; 10(381): 4-10.

36. Demiralay C, Wiedermann K. Influence of exogenous atrial natriuretic peptide on the noctural hypothalamic-pituary-adrenal axis and sleep i healthy men. Psych Neur Endo. 2010; 10: 1438-1445.

37. Więcek A, Januszewicz A, Szczepańska-Sadowska E. ed. Nadciśnienie tętnicze. Medycyna Praktyczna, Kraków 2018.

38. Forte M, Madonna M, Schiavon S, et al. Cardiovascular pleiotropic effects of natriuretic peptides. Int J Mol Sci. 2019; 20(16), doi: 10.3390/ijms20163874, indexed in Pubmed: 31398927.

39. Gojowy D, Więcek A. Co nowego w patogenezie nadciśnienia sodozależnego? In: Więcek A. ed. Postępy w nefrologii i nadciśnieniu tętniczym. Medycyna Praktyczna, Kraków 2019: 15-21.

40. Pandey KN. Genetic ablation and guanylyl cyclase/natriuretic peptide receptor-A: impact on the pathophysiology of cardiovascular dysfunction. Int J Mol Sci. 2019; 20(16), doi: 10.3390/ijms20163946, indexed in Pubmed: 31416126.

41. Bordicchia M, Liu D, Amri EZ, et al. Cardiac natriuretic peptides act via p38 MAPK to induce the brown fat thermogenic program in mouse and human adipocytes. J Clin Invest. 2012; 122(3): 1022-1036, doi: 10.1172/JCI59701, indexed in Pubmed: 22307324.

42. Bordicchia M, Spannella F, Ferretti G, et al. PCSK9 is expressed in human visceral adipose tissue and regulated by insulin and cardiac natriuretic peptides. Int J Mol Sci. 2019; 20(2), doi: 10.3390/ /ijms20020245, indexed in Pubmed: 30634533.

43. Lagace TA. PCSK9 and LDLR degradation: regulatory mechanisms in circulation and in cells. Curr Opin Lipidol. 2014; 25(5): 387-393, doi: 10.1097/MOL.0000000000000114, indexed in Pubmed: 25110901.

44. Urban D, Pöss J, Böhm M, et al. Targeting the proprotein convertase subtilisin/kexin type 9 for the treatment of dyslipidemia and atherosclerosis. J Am Coll Cardiol. 2013; 62(16): 1401-1408, doi: 10.1016/j.jacc.2013.07.056, indexed in Pubmed: 23973703.

45. Sabatine MS, Giugliano RP, Keech AC, et al. FOURIER Steering Committee and Investigators. Evolocumab and clinical outcomes in patients with cardiovascular disease. N Engl J Med. 2017; 376(18): 1713-1722, doi: 10.1056/NEJMoa1615664, indexed in Pubmed: 28304224.

46. Tomlinson B, Hu M, Zhang Y, et al. Alirocumab for the treatment of hypercholesterolemia. Expert Opin Biol Ther. 2017; 17(5): 633-643, doi: 10.1080/14712598.2017.1305354, indexed in Pubmed: 28277798.

47. Ibrahim NE, McCarthy CP, Shrestha S, et al. Effect of neprilysin inhibition on various natriuretic peptide assays. J Am Coll Cardiol. 2019; 73(11): 1273-1284, doi: 10.1016/j.jacc.2018.12.063, indexed in Pubmed: 30898202.

48. Chen S, Cao P, Dong N, et al. PCSK6-mediated corin activation is essential for normal blood pressure. Nat Med. 2015; 21(9): 10481053, doi: 10.1038/nm.3920.

49. Egom EE. BNP and heart failure: preclinical and clinical trial data. J Cardiovasc TransI Res. 2015; 8(3): 149-157, doi: 10.1007/s12265015-9619-3, indexed in Pubmed: 25771949.

50. Korostyshevskaya IM, Maksimov VF, Rudenko NS. C-type natriuretic peptide: what, where and why? Neuro Behav Physiol. 2016; 46(8): 888-894, doi: 10.1007/s11055-016-0328-4.
51. Rahbi H, Narayan $H$, Jones DJL, et al. The uroguanylin system and human disease. Clin Sci (Lond). 2012; 123(12): 659-668, doi: 10.1042/CS20120021, indexed in Pubmed: 22877138.

52. Valentino MA, Lin JE, Snook AE, et al. A uroguanylin-GUCY2C endocrine axis regulates feeding in mice. J Clin Invest. 2011; 121(9): 3578-3588, doi: 10.1172/JCl57925, indexed in Pubmed: 21865642.

53. Lorenz JN, Nieman M, Sabo J, et al. Uroguanylin knockout mice have increased blood pressure and impaired natriuretic response to enteral $\mathrm{NaCl}$ load. J Clin Invest. 2003; 112(8): 1244-1254, doi: 10.1172/ /jci200318743.

54. Miyazaki T, Otani K, Chiba A, et al. A new secretory peptide of natriuretic peptide family, osteocrin, suppresses the progression of congestive heart failure after myocardial infarction. Circ Res. 2018; 122(5): 742-751, doi: 10.1161/CIRCRESAHA.117.312624, indexed in Pubmed: 29326144.

55. Cui K, Huang W, Fan J, et al. Midregional pro-atrial natriuretic peptide is a superior biomarker to $\mathrm{N}$-terminal pro-B-type natriuretic peptide in the diagnosis of heart failure patients with preserved ejection fraction. Medicine (Baltimore). 2018; 97(36): e12277, doi: 10.1097/ /MD.0000000000012277, indexed in Pubmed: 30200170.

56. Czech M, Opolski G, Zdrojewski T, et al. The costs of heart failure in Poland from the public payer's perspective. Polish programme assessing diagnostic procedures, treatment and costs in patients with heart failure in randomly selected outpatient clinics and hospitals at different levels of care: POLKARD. Kardiol Pol. 2013; 71(3): 224-232, doi: 10.5603/KP.2013.0032, indexed in Pubmed: 23575775.

57. Mapa potrzeb zdrowotnych w zakresie kardiologii dla Polski. http://webcache.googleusercontent.com/search?q=cache:0m3bKiL7cEcJ:www. mz.gov.pl/wp-content/uploads/2015/12/MPZ_kardiologia_Polska. $p d f+\& c d=11 \& h l=e n \& c t=c \mid n k \& g l=p l($ February 3, 2020).

58. Maisel AS, Duran JM, Wettersten N. Natriuretic peptides in heart failure: atrial and B-type natriuretic peptides. Heart Fail Clin. 2018; 14(1): 13-25, doi: 10.1016/j.hfc.2017.08.002, indexed in Pubmed: 29153197.

59. Troughton RW, Richards AM, Yandle TG, et al. The effects of medications on circulating levels of cardiac natriuretic peptides. Ann Med. 2007; 39(4): 242-260, doi: 10.1080/07853890701232057, indexed in Pubmed: 17558597.

60. Ellinor PT, Low AF, Patton KK, et al. Discordant atrial natriuretic peptide and brain natriuretic peptide levels in lone atrial fibrillation. J Am Coll Cardiol. 2005; 45(1): 82-86, doi: 10.1016/j.jacc.2004.09.045, indexed in Pubmed: 15629379.

61. Baba M, Yoshida K, leda M. Clinical applications of natriuretic peptides in heart failure and atrial fibrillation. Int J Mol Sci. 2019; 20(11), doi: 10.3390/ijms20112824, indexed in Pubmed: 31185605.

62. Richards M, Di Somma S, Mueller C, et al. Atrial fibrillation impairs the diagnostic performance of cardiac natriuretic peptides in dyspneic patients: results from the BACH Study (Biomarkers in ACute Heart Failure). JACC Heart Fail. 2013; 1(3): 192-199, doi: 10.1016/j. jchf.2013.02.004, indexed in Pubmed: 24621869.

63. Knudsen $\mathrm{CW}$, Omland $\mathrm{T}$, Clopton $\mathrm{P}$, et al. Impact of atrial fibrillation on the diagnostic performance of B-type natriuretic peptide concentration in dyspneic patients: an analysis from the breathing not properly multinational study. J Am Coll Cardiol. 2005; 46(5): 838-844, doi: 10.1016/j.jacc.2005.05.057, indexed in Pubmed: 16139134.

64. O'Connor CM, Starling RC, Hernandez AF, et al. Effect of nesiritide in patients with acute decompensated heart failure. N Engl J Med. 
2011; 365(1): 32-43, doi: 10.1056/NEJMoa1100171, indexed in Pubmed: 21732835.

65. Sridharan S, Kini RM, Richards AM. Venom natriuretic peptides guide the design of heart failure therapeutics. Pharmacol Res. 2020; 155: 104687, doi: 10.1016/j.phrs.2020.104687, indexed in Pubmed: 32057893.

66. Costello-Boerrigter LC, Schirger JA, Miller WL, et al. Cenderitide (CD$-N P)$, a novel peptide designed to activate both guanylyl cyclase $B$ and $A$, activates the second messenger cGMP, suppresses aldosterone, and preserves GFR without reducing blood pressure in a proof-of-con- cept study in patients with chronic heart failure. BMC Pharmacology. 2011; 11(S1), doi: 10.1186/1471-2210-11-s1-p18.

67. Cannone V, Cabassi A, Volpi R, et al. Jr. Atrial natriuretic peptide: a molecular target of novel therapeutic approaches to cardio-metabolic disease. Int J Mol Sci. 2019; 20(13), doi: 10.3390/ijms20133265, indexed in Pubmed: 31269783.

68. Packer M, O'Connor C, McMurray JJV, et al. TRUE-AHF Investigators. Effect of ularitide on cardiovascular mortality in acute heart failure. N Engl J Med. 2017; 376(20): 1956-1964, doi: 10.1056/NEJMoa1601895, indexed in Pubmed: 28402745. 